\title{
Diclofenac-Induced Cytotoxicity in Cultured Carp Leukocytes
}

\author{
Monika NEMCOVA ${ }^{1,2}$, Jiri PIKULA ${ }^{1,2}$, Jan ZUKAL ${ }^{3,4}$, Veronika SEIDLOVA ${ }^{1,2}$ \\ ${ }^{1}$ Department of Ecology and Diseases of Zoo Animals, Game, Fish and Bees, University of \\ Veterinary and Pharmaceutical Sciences Brno, Brno, Czech Republic, ${ }^{2}$ Department of Zoology, \\ Fisheries, Hydrobiology and Apiculture, Mendel University in Brno, Czech Republic, ${ }^{3}$ Institute of \\ Vertebrate Biology of the Czech Academy of Sciences v.v.i., Brno, Czech Republic, ${ }^{4}$ Institute of \\ Botany and Zoology, Masaryk University, Brno, Czech Republic
}

Received October 10, 2020

Accepted October 26, 2020

\begin{abstract}
Summary
Diclofenac is a drug commonly used in human and veterinary medicine for the treatment of diseases associated with inflammation and pain. Medicinal products enter waste and surface waters on an everyday basis and contaminate the aquatic environment. Fish are therefore permanently exposed to these chemicals dissolved in their aquatic environment. To simulate variable environmental conditions, the aim of our study was to examine adverse effects of diclofenac under different temperatures of cell incubation $\left(18,21,24,27\right.$ and $\left.30^{\circ} \mathrm{C}\right)$. Cytotoxic and -static effects of diclofenac in concentrations of $0.001 \mu \mathrm{g} / \mathrm{ml}, 0.01 \mu \mathrm{g} / \mathrm{ml}, 0.1 \mu \mathrm{g} / \mathrm{ml}, 1 \mu \mathrm{g} / \mathrm{ml}, 10 \mu \mathrm{g} / \mathrm{ml}$ and $100 \mu \mathrm{g} / \mathrm{ml}$ for the carp (Cyprinus carpio) cultured leukocytes were quantified using detection of lactate dehydrogenase released from damaged cells. Overall DCF cytotoxicity was relatively low and its impact was pronounced at higher temperature and DCF concentration. Cells growth inhibition is changing more rapidly but it is high mainly at the highest concentration from low temperature. DNA fragmentation was not detected in tested leukocyte cell line. CYP450 increased diclofenac cytotoxicity only at the highest concentration but at incubation temperatures 18 and $27{ }^{\circ} \mathrm{C}$. Leukocyte viability is essential for immune functions and any change can lead to reduction of resistance against pathogens, mainly in cold year seasons, when the immune system is naturally suppressed.
\end{abstract}

\section{Key words}

Fish • Immune system • Non-steroidal anti-inflammatory drug • Toxicity • Temperature variation • Environmental pollution

\section{Corresponding author}

V. Seidlova, Department of Ecology and Diseases of Zoo Animals,
Game, Fish and Bees, University of Veterinary and Pharmaceutical Sciences Brno, Palackého tř. 1946/1, 61242 Brno, Czech Republic. E-mail: seidlovav@vfu.cz

\section{Introduction}

Human and wildlife health and disease are intricately interlinked (Forget and Lebel 2001, Zinsstag et al. 2011). Development and use of efficient drugs improves the quality of human and animal life. On the other hand, industrially produced medicinal products are mostly non-natural, hence, adverse effects from environmental drug residues may be a serious cause for concern (Arnold et al. 2013, Hruba et al. 2019, Mezzelani et al. 2016). Pharmaceuticals can influence aquatic organisms as well as contaminate ground and drinking water sources and other parts of ecosystems.

Diclofenac, a non-steroidal anti-inflammatory drug (NSAID), is amongst the most widely prescribed medicines worldwide and, consequently, one of the most frequently detected compounds in waste and surface waters (McGettigan and Henry 2013, Schwaiger et al. 2004). It is used in the treatment of pain, physical disability in rheumatic diseases as well as for its antiinflammatory and antipyretic effects (Kołodziejska and Kołodziejczyk 2018). In general, diclofenac, as a nonselective cyclooxygenase (COX) inhibitor, acts on both types of COX, namely COX-2 synthesized during inflammatory processes (therapeutic effect) and COX-1 with physiological function in synthesis of prostaglandins, which are important for protection of gastrointestinal epithelial cells (Hawkey 2000, Laine 
1996), for blood pressure balance, correct thrombocyte aggregation and some other cardiovascular system characteristics (Al-Saeed 2011, Grosser et al. 2006). Therefore, adverse effects are commonly associated with the above-mentioned systems (Al-Saeed 2011, Laine 1996). Importantly, however, detoxification and elimination pathways of xenobiotics including diclofenac are located in the liver and kidney, where diclofenac can be concentrated and/or metabolized by the enzyme complex of cytochrome P450 (CYP450) to form toxic metabolites (Boelsterli 2002, Shen et al. 1999, Tang et al. 1999). Nephro- (Hickey et al. 2001, Murray and Brater, 1993) and hepato-toxicity (Aithal and Day 2007, Helfgott et al. 1990) can be observed consequently.

The primary source of drugs and their metabolites in the environment are patients. The active substances and/or their metabolites are excreted in faeces and urine. First, pollutants contaminate wastewater treatment plants where they should ideally be eliminated. However, imperfectly captured micropollutants pose a risk because "treated" wastewater is released into the environment. Second, drugs used to treat animals can directly get into the soil with manure and later they may be flushed with rainwater. Expired drugs entering the cycle in the form of seepage from landfills is another source of pollution (Lonappan et al. 2016, Zuccato et al. 2000).

The dose, chemical structure and route of administration are important factors influencing the environmental burden of each biologically active substance (Daughton and Ruhoy 2013). Environmental studies revealed concentrations amounting up to a few hundred nanograms of diclofenac per liter of water. In the Czech Republic, the highest observed value of $1080 \mathrm{ng} / \mathrm{l}$ was detected in the Elbe river with relatively high flow rate of more than $60 \mathrm{~m}^{3} / \mathrm{s}$. At the same time, significantly higher levels of diclofenac residues can be detected in smaller watercourses with low flow rate, rural localities with intensive agriculture, in rivers below wastewater treatment plants and in the lower parts of streams (Buser et al. 1998, Lacina et al. 2013, Marsik et al. 2017, Tixier et al. 2003, Ternes, 1998).

While diclofenac concentrations detected in water usually do not induce acute toxicity with lethal effects (Lonappan et al. 2016), it accumulates in fish organs in a concentration-dependent manner (Schwaiger et al. 2004). It was found that fish show abnormal behavior, respiratory distress, changes in biochemical and hematological parameters and pathological alterations in the liver, kidney and gills suggestive of inflammatory and necrotic processes associated with exposure to diclofenac (Ajima et al. 2015, Hoeger et al. 2005, Schwaiger et al. 2004, Stepanova et al. 2013), resulting in general health impairment (Schwaiger et al. 2004).

The majority of ecotoxicology experiments were designed to examine effects of diclofenac at the level of whole fish organisms (Ajima et al. 2015, Hoeger et al. 2005, Schwaiger et al. 2004, Stepanova et al. 2013), maintaining a narrow range of aquarium water parameters including the temperature. Immune defences of nonhomeothermic vertebrates are temperature-dependent (Heger et al. 2020, Morvan et al. 1998). While immunotoxicity of diclofenac in fish is still understudied (Schwaiger et al. 2004), fish cell cultures provide useful tools for experimental approaches with temperature variation. Here, we performed diclofenac toxicity testing using cultured carp leukocytes and predicted both higher cytotoxicity rates and proliferation inhibition at lower temperatures. We also aimed to obtain data applicable for environmental pollution risk evaluation of diclofenac in the common carp (Cyprinus carpio), an important aquaculture species.

\section{Materials and Methods}

\section{Cell line and chemicals}

We used common carp (Cyprinus carpio) leukocytes cell culture number 95070628 (Merck SigmaAldrich, Germany) for diclofenac toxicity testing. Following chemicals were used during cultivation and testing: culture medium Dulbecco's Modified Eagle Medium/Ham's F-12 (1:1), assay medium Dulbecco's Modified Eagle Medium (DMEM) w/o sodium pyruvate, bovine calf serum (BCS) $10 \%$, antibiotics (ATB) (penicillin $100 \mathrm{IU} / \mathrm{ml}$ and streptomycin $100 \mu \mathrm{g} / \mathrm{ml}$, Biosera, Boussens, France), diclofenac sodium salt (Sigma-Aldrich, Germany), 1A2 Cytochrome P450 human expressed in Pichia pastoris (CYP450) (Merck, Sigma-Aldrich, Germany), lactate-dehydrogenase (LDH) activity assay kit (Roche Sigma-Aldrich, Germany), dimethyl sulfoxide (DMSO), phosphate saline buffer, and trypsin solution (Sigma-Aldrich, Germany).

\section{Solutions for treatment of cultures}

After reduction of light intensity in the laboratory, diclofenac was solubilized in DMSO and diluted with DMEM w/o sodium pyruvate to obtain final testing concentrations of diclofenac. Two experiments 
with different concentrations of diclofenac were performed (see Table 1). The tested concentration range started with $1 \mathrm{ng} / \mathrm{ml}$ based on the value detected in the Elbe river (Marsik et al. 2017). It can also be assumed that diclofenac concentrations in the aquatic environment can be higher than the observed values due to accumulation of residues in the environment (Marsik et al. 2017) and in organs and tissues of fish (Schwaiger et al. 2004). Moreover, higher tested concentrations were selected in order to induce distinct cytotoxic effects (cell killing versus growth rate inhibition), suggestive of the fact that leukocytes are more resistant to diclofenac than other cell types (Němcová, 2018).

\section{Cytotoxicity assay}

The number of injured cells was assessed through measuring intracellular lactate dehydrogenase leakage from damaged cells using LDH activity assay kit according to the manufacturer's instructions. Absorbance of product of reaction was measured at $490 \mathrm{~nm}$ using ELISA reader (Elx808, BioTek, USA). For calculation of cytotoxic and inhibition effects we used modified protocol according to Smith et al. (2011).

\section{Detection of DNA fragmentation}

After the cultured cell pellet was obtained by centrifugation (1000 rpm for $6 \mathrm{~min}$ ) of the cell suspension (the medium was removed and cells were detached from the cultivation surface using trypsin solution). DNA for detection of DNA fragmentation was isolated using NucleoSpin ${ }^{\circledR}$ Tissue (Macherey-Nagel GmbH \& Co. KG, Dueren, Germany). Isolated DNA was then analyzed by electrophoresis in $2.5 \%$ agarose gel $(100 \mathrm{~V}$ for $90 \mathrm{~min}$, $50 \mathrm{~V}$ for $50 \mathrm{~min}, 35 \mathrm{~V}$ for $50 \mathrm{~min}$ ) after staining with DNA Stain G (SERVA, Heidelberg, Germany) and visualisation on a UV transilluminator (Ultra Lum Inc., Claremont, Canada).

Experiment 1: Influence of diclofenac sodium salt on carp leukocytes

Cells in 96-well plates (10 000 cells/well for $12 \mathrm{~h}, 8000$ cells/well for 24 and $48 \mathrm{~h}$ ) were pre-incubated (Benchmark, myTemp ${ }^{\mathrm{TM}}$ Mini $\mathrm{CO}_{2}$, USA) overnight in medium DMEM-F12 supplemented with $10 \%$ BCS and $1 \%$ ATB under humidified atmosphere of $5 \% \mathrm{CO}_{2}$ at $27^{\circ} \mathrm{C}$. Then the medium was replaced with diclofenacsupplemented or control solutions (see Table 1). The treated cells were incubated (ESCO, CellCulture $\mathrm{CO}_{2}$, USA) in the dark under humidified atmosphere of $5 \%$ $\mathrm{CO}_{2}$ at five different temperatures of 18, 21, 24, 27 and $30{ }^{\circ} \mathrm{C}$. To determine cytotoxicity, we detected lactate dehydrogenase released from damaged cells after 12, 24 and $48 \mathrm{~h}$ of exposure.

Table 1. Experimental design information

\begin{tabular}{|c|c|c|c|c|c|c|c|c|c|c|}
\hline & \multicolumn{10}{|c|}{ Experiment 1} \\
\hline \multicolumn{2}{|c|}{ DCF concentration } & $\begin{array}{c}\text { control } \\
\text { with cells } \\
(0 \mu \mathrm{g} / \mathrm{ml}) \\
*\end{array}$ & $\begin{array}{c}\text { control } \\
\text { blank } \\
(0 \mu \mathrm{g} / \mathrm{ml}) \\
*\end{array}$ & $\begin{array}{l}\text { test blank } \\
(100 \\
\mu \mathrm{g} / \mathrm{ml}) \\
*\end{array}$ & $\begin{array}{l}0.001 \\
\mu \mathrm{g} / \mathrm{ml}\end{array}$ & $\begin{array}{c}0.01 \\
\mu \mathrm{g} / \mathrm{ml}\end{array}$ & $0.1 \mu \mathrm{g} / \mathrm{ml}$ & $1 \mu \mathrm{g} / \mathrm{ml}$ & $10 \mu \mathrm{g} / \mathrm{ml}$ & $\begin{array}{c}100 \\
\mu \mathrm{g} / \mathrm{ml}\end{array}$ \\
\hline \multirow{4}{*}{\multicolumn{2}{|c|}{ DMSO concentration }} & \multicolumn{9}{|c|}{ not exceeding $0.5 \%$} \\
\hline & & \multicolumn{9}{|c|}{ Experiment 2} \\
\hline & & \multicolumn{9}{|c|}{ DCF concentration } \\
\hline & & \multicolumn{4}{|c|}{ DCF $0 \mu \mathrm{g} / \mathrm{ml}$} & \multicolumn{5}{|c|}{ DCF $100 \mu \mathrm{g} / \mathrm{ml}$} \\
\hline $\begin{array}{l}\text { CYP } \\
\text { concentration }\end{array}$ & $\begin{array}{c}\text { CYP450 } \\
0 \mu \mathrm{g} / \mathrm{ml} \\
\text { CYP450 } \\
0.5 \mu \mathrm{g} / \mathrm{ml} \\
\text { CYP450 } \\
5 \mu \mathrm{g} / \mathrm{ml}\end{array}$ & & control & with cells & & & & $*$ & & \\
\hline \multicolumn{2}{|c|}{ DMSO concentration } & \multicolumn{9}{|c|}{ not exceeding $0.5 \%$} \\
\hline
\end{tabular}

$\mathrm{DCF}=$ diclofenac; $\mathrm{DMSO}=$ dimethyl sulfoxide; cytochrome $=\mathrm{CYP}$ 
Experiment 2: Influence of diclofenac metabolism in carp leukocytes on cytotoxicity

Cells in plates ( 8000 cells/well in 96 -wells plate for LDH assay or 50000 cells/well in 6-wells plate for DNA isolation) were pre-incubated overnight in DMEMF12 supplemented with $10 \%$ BCS and $1 \%$ ATB under humidified atmosphere of $5 \% \mathrm{CO}_{2}$ at $27{ }^{\circ} \mathrm{C}$. The medium was then replaced with test solutions (Table 1). The treated cells were incubated in the dark under humidified atmosphere of $5 \% \quad \mathrm{CO}_{2}$ at different temperatures of $18{ }^{\circ} \mathrm{C}$ (sub-optimal cultivation temperature, immune response initiated in vivo), $27{ }^{\circ} \mathrm{C}$ (optimal temperature for cultivation recommended for carp cell cultures by the supplier (Merck Sigma-Aldrich, Germany) and researchers (Chen et al. 2009, Liu et al. 2015) and $30{ }^{\circ} \mathrm{C}$ (temperature over the optimal cultivation temperature range). Cytotoxicity was then measured in 96-wells plates using detection of lactate dehydrogenase released from damaged cells after 24 exposure. The 6-wells plates were used for DNA isolation to detect DNA fragmentation after $48 \mathrm{~h}$ of exposure.

\section{Data analysis}

Two parameters were calculated separately for any experimental well, i.e. percent killing (cytotoxicity) and percent inhibition according to Smith et al. (2011). Normal distribution of variables in each dataset was tested using the Shapiro-Wilk test. All results in Experiment 1 were obtained from five independent measurements but only two to four measurements were obtained during Experiment 2. The influence of categorical predictors (duration of cultivation, temperature of cultivation and diclofenac concentration) and their interactions to both dependent variables was calculated using Multi-Factorial ANOVA. Predictive desirability model was calculated according to Derringer and Suich (1980) with least square fitting. The relationship between cytotoxicity and inhibition values was analyzed by Pearson correlation coefficient. The difference between the CYP450 groups (Experiment 2) was calculated using one-way ANOVA followed by the Scheffe's post hoc test as there was no significant variance in homogeneity. $\mathrm{P}<0.05$ was considered a significant difference. All analyses were performed in Statistica for Windows ${ }^{\circledR} 13.2$ (StatSoft, Inc., Tulsa, OK, USA).

\section{Results}

\section{Experiment 1}

The longest incubation period $(48 \mathrm{~h})$ was excluded from the analysis because cytotoxicity results were extremely influenced by the increasing inhibition of cell growth (Fig. 1). This negative correlation was significant at all diclofenac concentrations except for $0.1 \mu \mathrm{g} / \mathrm{ml}$ ( $\mathrm{p}=0.069$ ) (Table 2) diclofenac cytotoxicity was generally low and does not occur within short periods of cell incubation and exposure $(12 \mathrm{~h})$. It was increased at temperatures of $24{ }^{\circ} \mathrm{C}$ and higher after $24 \mathrm{~h}$ of incubation reaching the highest average value of $21 \%$ (diclofenac concentration $100 \mu \mathrm{g} / \mathrm{ml}$ at cultivation temperature $27^{\circ} \mathrm{C}$ and $24 \mathrm{~h}$ ) (Fig. 2). Factorial ANOVA confirmed the influence of all analyzed factors (time, temperature, concentration) but the impact of concentration was not dependent on the other two factors (Table 3). On the contrary, cellular growth inhibition was also significantly influenced by all parameters under study and the whole model explained more than $80 \%$ of variability. Inhibition increased in response to increasing diclofenac concentrations right from the lowest incubation temperature $\left(18{ }^{\circ} \mathrm{C}\right)$ after the shortest incubation time (12 h) (Fig. 3). The different response of both dependent variables was confirmed also by predictive desirability models (Fig. 4).

\section{Experiment 2}

One-way ANOVA confirmed impact of CYP450 on carp leucocytes at the highest incubation temperature $\left(30{ }^{\circ} \mathrm{C}\right)$ (Table 4). Cytotoxicity of both CYP450 concentrations $(0.5 \mu \mathrm{g} / \mathrm{ml}$ and $5 \mu \mathrm{g} / \mathrm{ml})$ significantly differed from the control group (post-hoc Scheffe's test).

Table 2. Pearson correlation two diclofenac-induced effects (cytotoxicity versus inhibition of growth) in carp (Cyprinus carpio) leukocyte cultivated in vitro in Experiment 1, after 48 incubation hours.

\begin{tabular}{ccc}
\hline $\begin{array}{c}\text { Diclofenac } \\
\text { concentration }\end{array}$ & $\mathbf{r}$ & $\mathbf{p}$ \\
\hline $0.001 \mu \mathrm{g} / \mathrm{ml}$ & -0.563 & 0.003 \\
$0.01 \mu \mathrm{g} / \mathrm{ml}$ & -0.700 & $<0.001$ \\
$0.1 \mu \mathrm{g} / \mathrm{ml}$ & -0.370 & 0.069 \\
$1 \mu \mathrm{g} / \mathrm{ml}$ & -0.585 & 0.002 \\
$10 \mu \mathrm{g} / \mathrm{ml}$ & -0.548 & 0.005 \\
$100 \mu \mathrm{g} / \mathrm{ml}$ & -0.599 & 0.002 \\
\hline
\end{tabular}




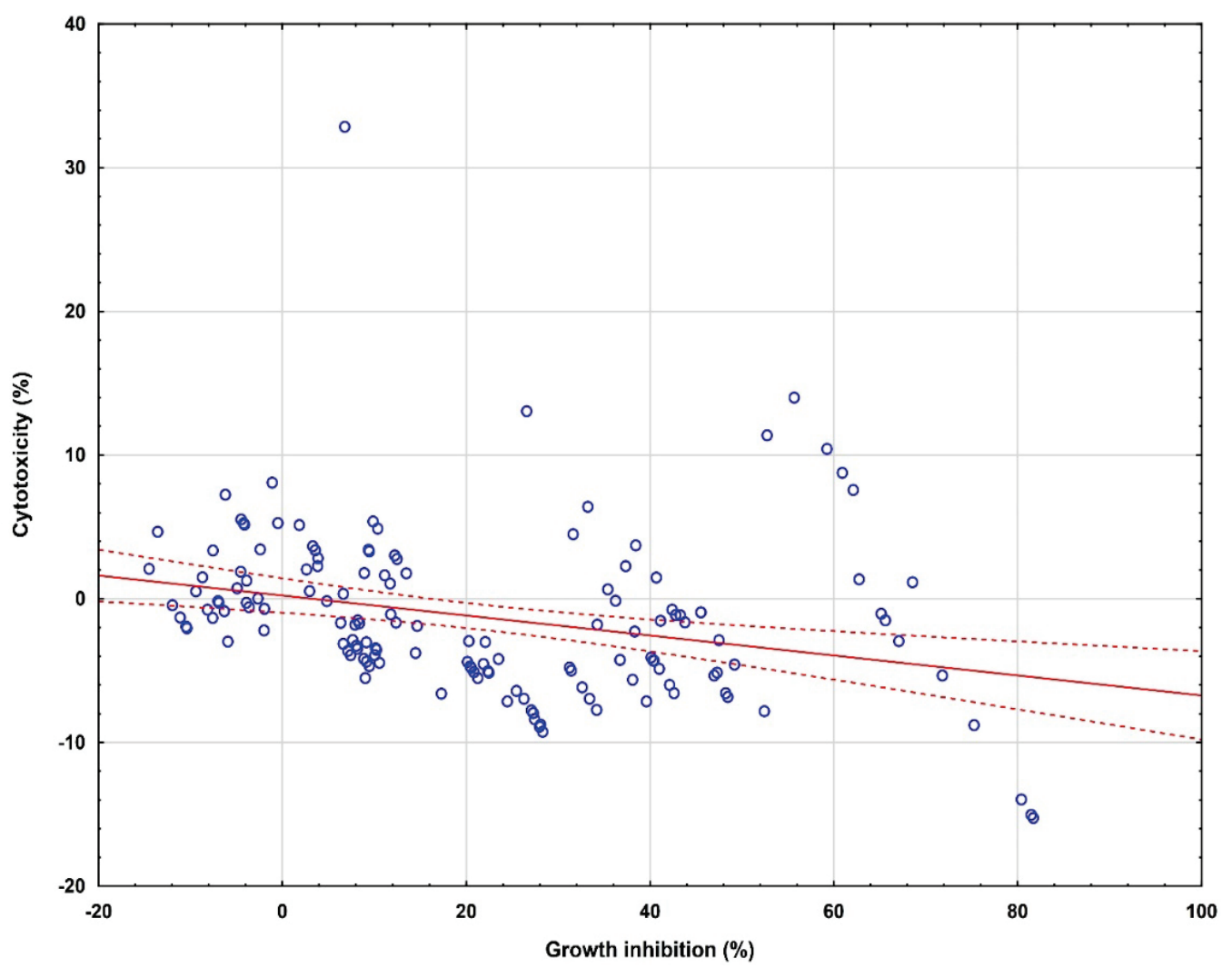

Fig. 1. The dependence of calculated percentage of cell death on growth inhibition level. The correlation between two observed cytotoxic effects (cell death versus inhibition of growth) caused by diclofenac in carp (Cyprinus carpio) leukocyte cultivated in vitro in Experiment 1, after 48 incubation hours at different temperatures $\left(18,21,24,27\right.$ and $\left.30^{\circ} \mathrm{C}\right)$. Cells were treated with various diclofenac concentrations $(0.001 \mu \mathrm{g} / \mathrm{ml}, 0.01 \mu \mathrm{g} / \mathrm{ml}, 0.1 \mu \mathrm{g} / \mathrm{ml}, 1 \mu \mathrm{g} / \mathrm{ml}, 10 \mu \mathrm{g} / \mathrm{ml}$ and $100 \mu \mathrm{g} / \mathrm{ml})$.
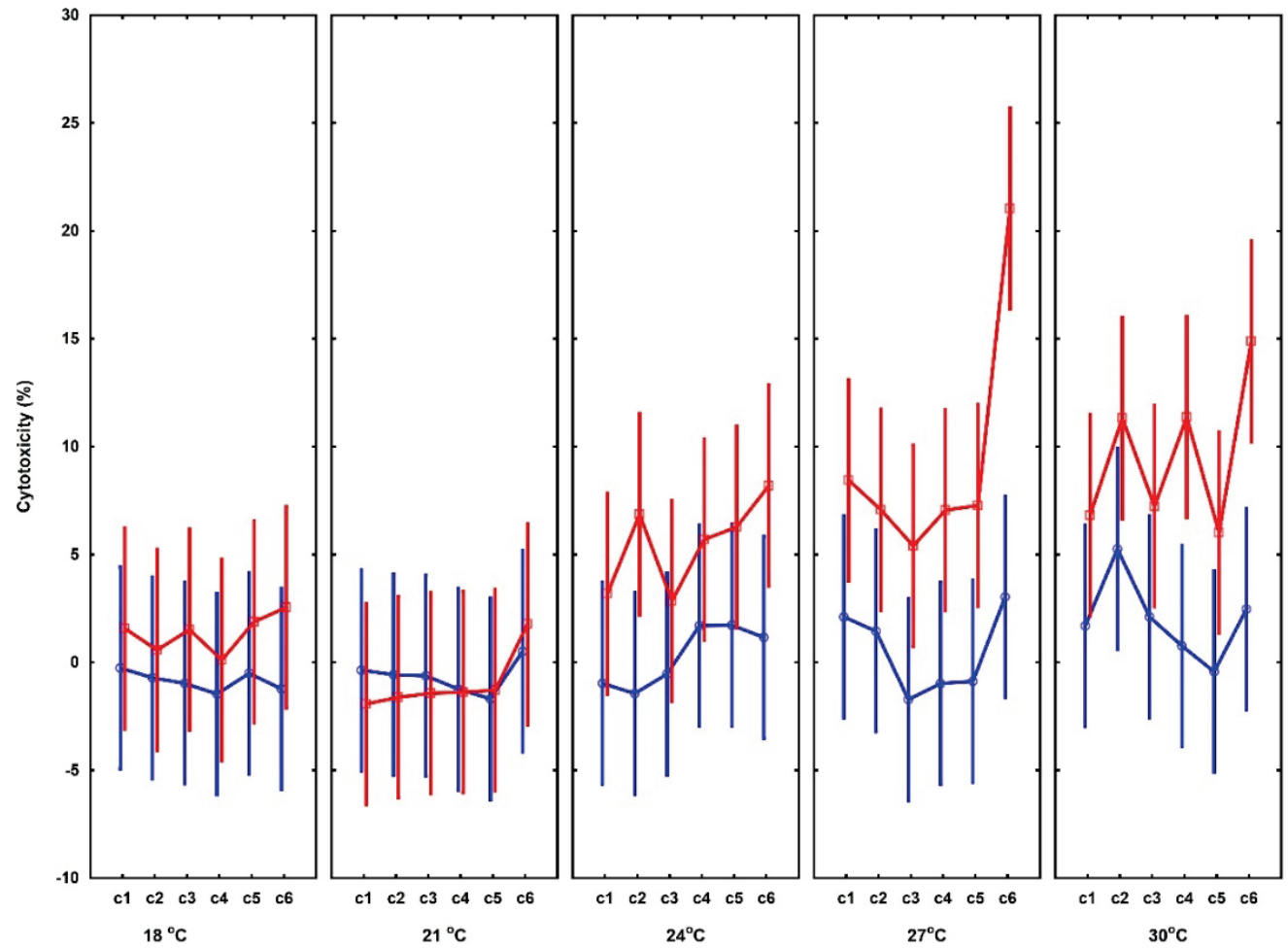

Fig. 2. Diclofenac-induced cytotoxicity in cultured carp (Cyprinus carpio) leuko-cytes. The percentage of killed carp leukocytes in Experiment 1, determined after 12 (blue line) and 24 (red line) hours of incubation at different temperatures $(18,21,24,27$ and $30^{\circ} \mathrm{C}$ ). Cells were treated with various concentrations diclofenac $(\mathrm{c} 1: 0.001 \mu \mathrm{g} / \mathrm{ml}, \mathrm{c} 2: 0.01 \mu \mathrm{g} / \mathrm{ml}, \mathrm{c} 3: 0.1 \mu \mathrm{g} / \mathrm{ml}, \mathrm{c} 4: 1 \mu \mathrm{g} / \mathrm{ml}, \mathrm{c} 5$ : $10 \mu \mathrm{g} / \mathrm{ml}$ and c6: $100 \mu \mathrm{g} / \mathrm{ml}$ ). 
Table 3. Results of factorial analysis of variance (ANOVA) of diclofenac-induced cytotoxic and cytostatic effects.

\begin{tabular}{|c|c|c|c|c|c|c|c|c|c|}
\hline \multirow[b]{2}{*}{ Effect } & \multirow[b]{2}{*}{ DF } & \multicolumn{4}{|c|}{ Cytotoxicity } & \multicolumn{4}{|c|}{ Growth inhibiton } \\
\hline & & SS & MS & $\mathbf{F}$ & $\mathbf{p}$ & SS & MS & $\mathbf{F}$ & $\mathbf{p}$ \\
\hline Intercept & 1 & 2040.08 & 2040.08 & 72.59 & $<0.001$ & 4077.66 & 4077.66 & 145.10 & $<0.001$ \\
\hline Time & 1 & 1679.22 & 1679.22 & 59.75 & $<0.001$ & 2886.32 & 2886.32 & 102.70 & $<0.001$ \\
\hline Temp & 4 & 1977.17 & 494.29 & 17.59 & $<0.001$ & 3127.83 & 781.96 & 27.83 & $<0.001$ \\
\hline$D C F$ conc & 5 & 533.21 & 106.64 & 3.79 & 0.003 & 18221.37 & 3644.27 & 129.67 & $<0.001$ \\
\hline $\begin{array}{l}\text { Time * } \\
\text { Temp }\end{array}$ & 4 & 864.10 & 216.03 & 7.69 & $<0.001$ & 2373.84 & 593.46 & 21.12 & $<0.001$ \\
\hline $\begin{array}{l}\text { Time * } \\
\text { DCF conc }\end{array}$ & 5 & 235.16 & 47.03 & 1.67 & 0.142 & 1148.07 & 229.61 & 8.17 & $<0.001$ \\
\hline $\begin{array}{l}\text { Temp * } \\
\text { DCF conc }\end{array}$ & 20 & 585.31 & 29.27 & 1.04 & 0.414 & 5172.37 & 258.62 & 9.20 & $<0.001$ \\
\hline Time * & & & & & & & & & \\
\hline $\begin{array}{l}\text { Temp * } \\
\text { DCF conc }\end{array}$ & 20 & 218.12 & 10.91 & 0.39 & 0.992 & 4387.2 & 219.36 & 7.81 & $<0.001$ \\
\hline
\end{tabular}

Time = duration of cultivation; Temp = temperature of cultivation; DCF conc = diclofenac concentration.
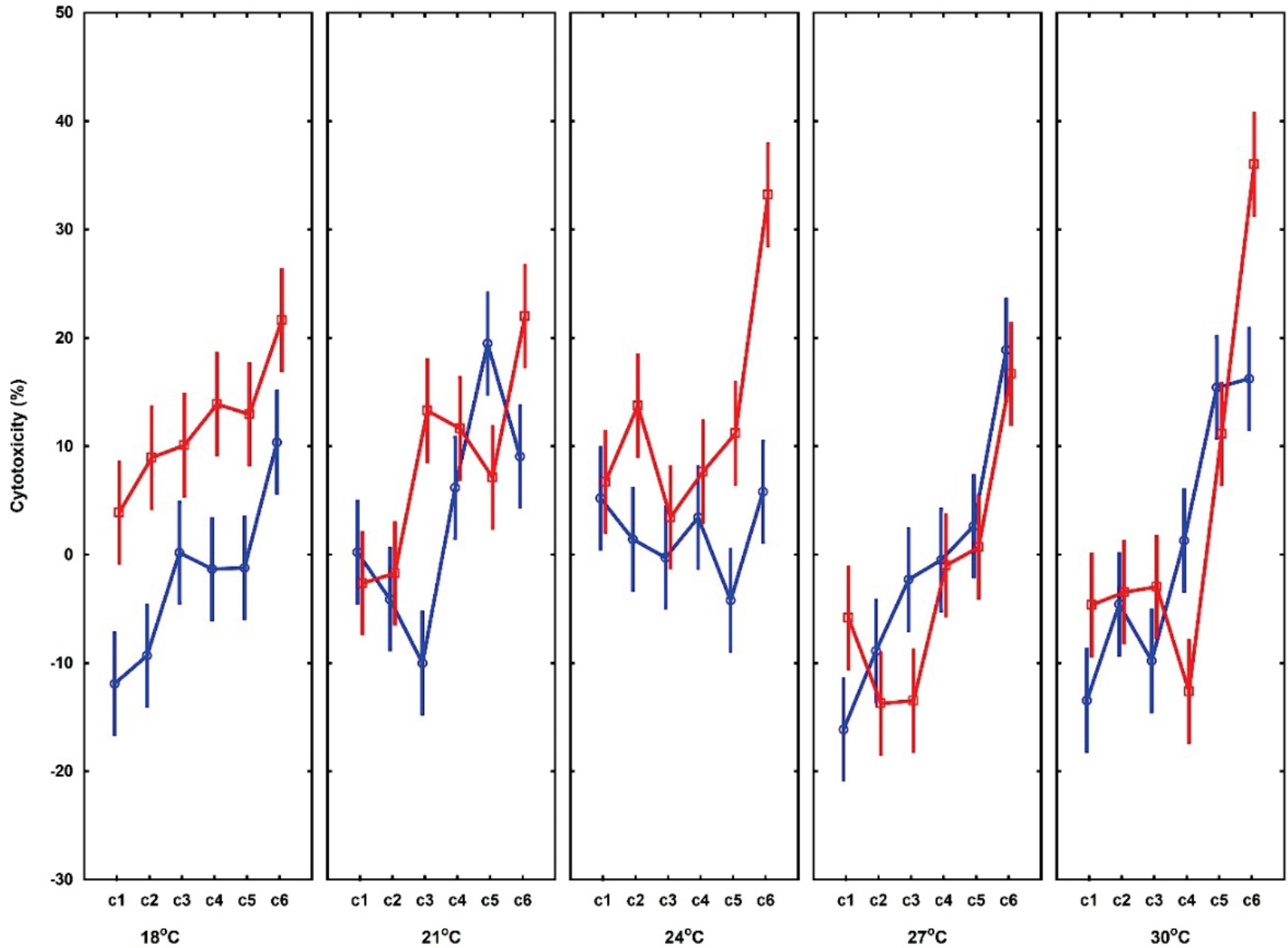

Fig. 3. Diclofenac-induced cytostatic effect in cultured carp (Cyprinus carpio) leukocytes. The percentage provides information about growth inhibition level in carp leukocyte cell culture in Experiment 1, determined after 12 (blue line) and 24 (red line) hours of incubation at different temperatures $\left(18,21,24,27\right.$ and $30^{\circ} \mathrm{C}$ ). Cells were treated with various concentrations diclofenac (c1: 0.001 $\mu \mathrm{g} / \mathrm{ml}, \mathrm{c} 2: 0.01 \mu \mathrm{g} / \mathrm{ml}, \mathrm{c3}: 0.1 \mu \mathrm{g} / \mathrm{ml}, \mathrm{c} 4: 1 \mu \mathrm{g} / \mathrm{ml}, \mathrm{c5}: 10 \mu \mathrm{g} / \mathrm{ml}$ and c6: $100 \mu \mathrm{g} / \mathrm{ml}$ ). 

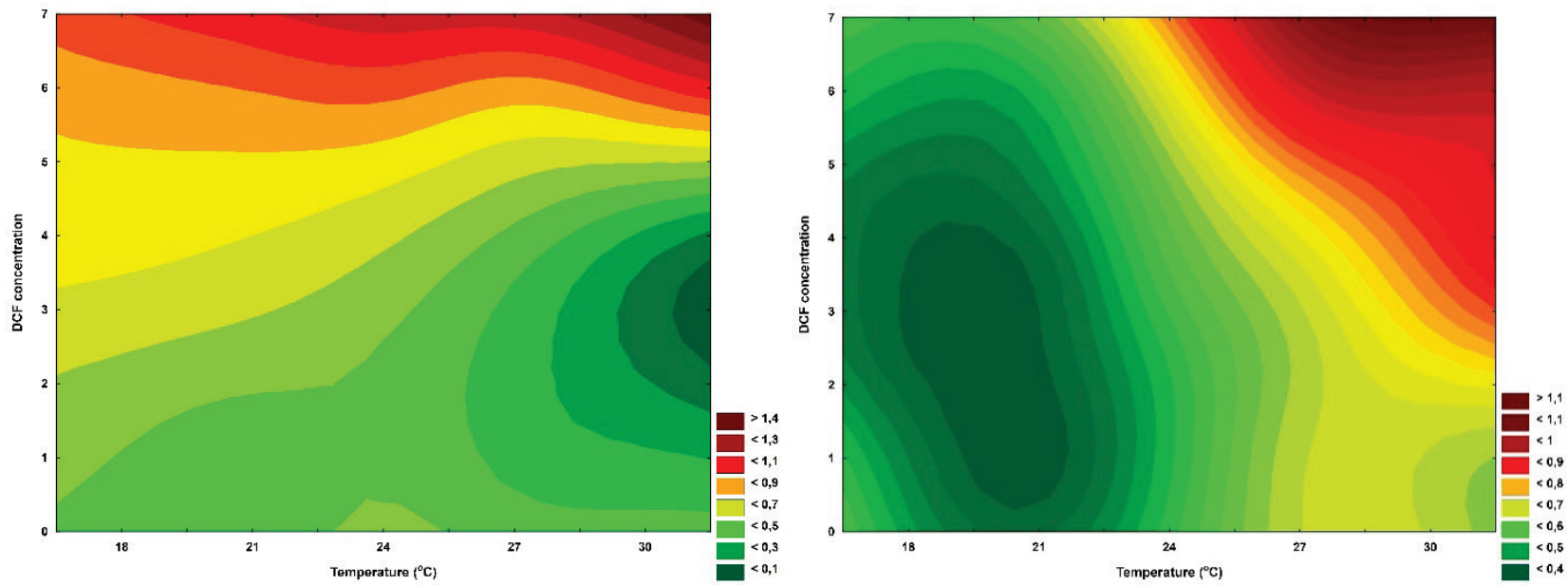

Fig. 4. Contour plots of the levels of overall response desirability for (a) diclofenac-induced cytotoxicity and (b) diclofenac-induced growth inhibition based on desirability profiling with the least squares fit. There is obvious difference in the response of analyzed parameters to the highest diclofenac concentration i.e. cytotoxic effect only at the highest temperatures but cytostatic effect at all temperatures.

Table 4. Results of one-way analysis of variance (ANOVA) of cytochrome P450 cytotoxic effect.

\begin{tabular}{lccccc}
\hline & & & \multicolumn{3}{c}{ Scheffe's post-hoc test } \\
\cline { 4 - 6 } Temperature & F & $\mathbf{p}$ & $\begin{array}{c}\text { control vs low } \\
\text { CYP }\end{array}$ & $\begin{array}{c}\text { control vs high } \\
\text { CYP }\end{array}$ & $\begin{array}{c}\text { low CYP vs } \\
\text { high CYP }\end{array}$ \\
\hline $18^{\circ} \mathrm{C}$ & 3.614 & 0.084 & 0.967 & 0.138 & 0.122 \\
$27^{\circ} \mathrm{C}$ & 13.539 & 0.003 & 0.073 & 0.176 & 0.003 \\
$30^{\circ} \mathrm{C}$ & 22.125 & $<0.001$ & 0.041 & $<0.001$ & 0.018 \\
\hline
\end{tabular}

Control = cells treated only with $100 \mu \mathrm{g} / \mathrm{ml}$ of diclofenac; low CYP = cells treated with $100 \mu \mathrm{g} / \mathrm{ml}$ of diclofenac and $0.5 \mu \mathrm{g} / \mathrm{ml}$ cytochrome P450; high CYP = cells treated with $100 \mu \mathrm{g} / \mathrm{ml}$ of diclofenac and $5.0 \mu \mathrm{g} / \mathrm{ml}$ cytochrome P450.

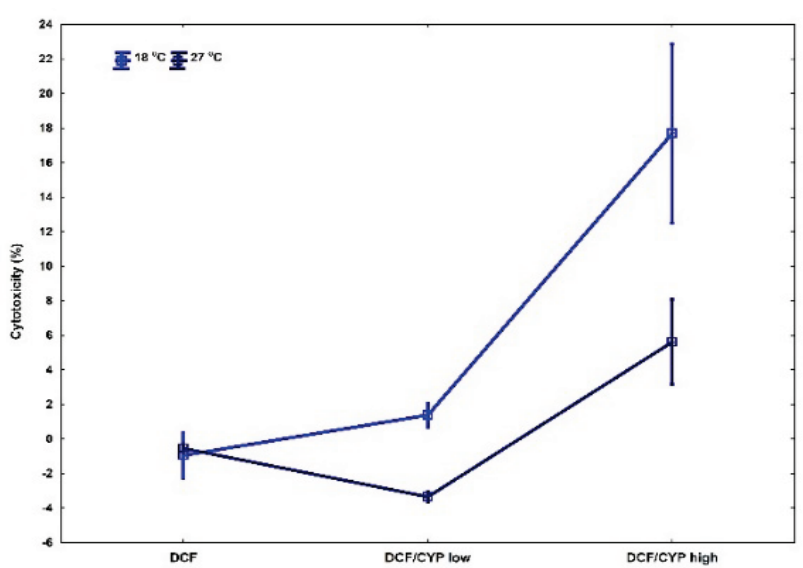

Fig. 5. Cytotoxic effect caused by combination of diclofenac and cytochrome P450 in carp (Cyprinus carpio) leukocyte cultivated in vitro. The percentage of killed carp leukocytes in Experiment 2, determined after 24 hours of incubation at different temperatures $\left(18\right.$ and $27^{\circ} \mathrm{C}$ ). Cells were treated with $100 \mu \mathrm{g} / \mathrm{ml}$ of diclofenac (DCF) in combination with different cytochrome P450 concentrations (CYP low: $0.5 \mu \mathrm{g} / \mathrm{ml}$ or CYP high: $5 \mu \mathrm{g} / \mathrm{ml}$ ).
Therefore, we excluded the experimental group incubated at $30{ }^{\circ} \mathrm{C}$ from the subsequent analysis. Combined impact of diclofenac and CYP450 significantly differed at the higher concentration of CYP450. The average cytotoxicity reached the highest values for both incubation temperatures, $17.7 \%$ and $5.6 \%$, respectively (Fig. 5). DNA fragmentation was not detected in the tested leukocyte cell line following exposure to diclofenac.

\section{Discussion}

Leukocytes are an essential part of the immune system playing an important role in defence against pathogenic agents. The number of viable leukocytes is one of key factors for maintaining individual's health. Even a low decrease in viability of these cells can weaken the organism and intensify its susceptibility to disease (Beutler 2004, Desai et al. 2010, Neumann et al. 2001, 
Turvey and Broide 2010). Therefore, our study aimed to investigate the response of cultured carp leukocytes (percentage of viable versus dead cells and growth inhibition) following exposure to diclofenac, a frequent aquatic environment contaminant around the world (Buser et al. 1998, Lacina et al. 2013, Marsik et al. 2017, Tixier et al. 2003, Ternes 1998). Moreover, toxicity of diclofenac and any other environmental pollutant may be enhanced by interaction with other anthropogenic xenobiotics or naturally-occurring toxins (Cleuvers 2004, Osickova et at. 2014, Paskova et al. 2011), posing a threat for wildlife species and whole ecosystems (Owa 2013).

While in fish exposed to diclofenac, the number of white blood cells at organismal level slightly increases (Ajima et al. 2015), similar to homeotherms (Lim et al. 2006, Martinez et al. 1999), little is known about diclofenac effects at the cellular level, despite existence of standardized ethically acceptable in vitro methods and fish-derived cell and tissue cultures which may provide scientifically correct targeted results and help understand toxicological processes in vivo (May et al. 2009, Orbach et al. 2017, Wilhelm et al. 2011). Our in vitro results show that cultured carp leukocytes after short-term (12 h) exposure to diclofenac proliferate slightly (Fig. 2), suggesting an initial response to the drug (Ajima et al. 2015), and the percentage of damaged cells during the first approximately $8 \mathrm{~h}$ (i.e. necrotic cell death) is low (Niles et al. 2009). In general, however, exposure to NSAIDs leads more to apoptosis than necrosis (Ajima et al. 2015, Chang et al. 2005, Nicotera et al. 1999, Niles et al. 2009). Therefore, cytotoxicity increases after medium-term (24 h) and longer exposure to diclofenac.

The original LDH-based cytotoxicity protocol grossly underestimates the proportion of dead cells under conditions with cell growth inhibition (Smith et al. 2011). We used, therefore, the modified protocol recommended by the above authors (Smith et al. 2011), differentiating two cytotoxic effects, i.e. cell death versus growth inhibition. According to this protocol, the calculated percentage of killed cells is still influenced by growth inhibition (Fig. 1). The equation used in the protocol is calculated with "low control values", while non-exposed control cells natural mortality is high, because proliferation of non-exposed cells is significantly higher compared with inhibited test cells as having more cells means more natural deaths (as shown in experiments of longer-term duration 48 h, Fig. 1). In line with this finding, the LDH test as such is not quite relevant for experiments with exposures lasting $48 \mathrm{~h}$ and more.
The highest percentage of damaged cells was $21 \%$, yet, the number of leukocytes in the culture continuously decreased over time (Fig. 3 and 4). These results suggest that diclofenac inhibits cell proliferation (Chang et al. 2005, 2006) rather than induces cell destruction by necrosis or apoptosis. Importantly, at temperatures lower than the optimal cultivation temperature range of $24-28{ }^{\circ} \mathrm{C}$ recommended for carp cell cultures (Chen et al. 2009, Liu et al. 2015), proliferation of both exposed and non-exposed control cells is reduced by the low temperature (Carey et al. 2003, Stephenson, 1966). Likewise, many physiological processes are influenced by the body temperature corresponding with the ambient temperature in poikilotherm fish. Low temperatures suppress immune responses (Bly and Clem, 1991), cell proliferation, differentiation, tissue remodelling and generally growth rate (Harding et al. 2016, Neuheimer et al. 2011). Thus, renewal of leukocytes is generally slow at low temperatures.

Cytotoxic (Bort et al. 1999, Ponsoda et al. 1995, Syed et al. 2016) and cytostatic (van Leeuwen et al. 2011) effects were reported to be influenced by diclofenac metabolisation mediated by CYP P450. Cytochrome P450 enzyme complex addition combined with exposure to diclofenac, however, had no significant influence on the performance of cultured carp leukocytes in the present study, probably due to the fact that blood leukocytes are not primarily active in detoxication of xenobiotics (Filkins 1971) and may not be able effectively utilize CYP P450 to produce cytotoxic metabolites. On the other hand, the combination of high concentration of CYP P450 and diclofenac had a significantly higher cytotoxic effect than other conditions tested in our experiment 2 (Fig. 5). At the surfeit of CYP P450, leukocytes start work with CYP $\mathrm{P} 450$ either as a catalyst of detoxifying reactions or the high level of CYP P450 acts as a xenobiotic (cf. temperature $30{ }^{\circ} \mathrm{C}$, Table 4). Understandably, resistance/ susceptibility of leukocytes and other organs/tissuesderived cells to adverse effects of xenobiotics, including diclofenac, will be variable under in vitro conditions (Němcová 2018). Likewise, in vivo studies show that cell damage by diclofenac-induced oxidative stress is significantly lower in blood compared with liver and/or gill cells (Islas-Flores et al. 2013). The oxidative stress is known to affect one of the pathways of leukocyte apoptosis. A possible pathological mechanism is associated with reactive oxygen species-induced DNA damage (Krammer et al. 2007, Krüger and Mooren 
2014). While DNA fragmentation due to diclofenacinduced oxidative stress was not detected in our experiment with cultured carp leukocytes, oxidative stress induced by diclofenac coupled with massive DNA fragmentation as early as $24 \mathrm{~h}$ after exposure to diclofenac in other cell types (Hickey et al. 2001). Activated leukocytes develop a certain degree of apoptosis resistance to decrease their cell population damage (Krammer et al. 2007, Krüger and Mooren 2014).

To conclude, exposure to diclofenac resulted in reduction of leukocyte numbers through inhibition of cell proliferation and decreasing their viability in vitro. Environmental contamination by diclofenac represents, therefore, a burden for the immune system of fish. While cell culture experimental models are useful for identifying and understanding environmental pollution problems in line with the 'Three Rs' concept of animal welfare and protection against cruelty, extrapolation of cellular effects for the whole organism in vivo is still a challenge (Abdelsalam et al. 2020, Kovacova et al. 2016).

\section{Conflict of Interest}

There is no conflict of interest.

\section{Acknowledgements}

This study/paper was supported by the project PROFISH CZ.02.1.01/0.0/0.0/16_019/0000869. The project is financed by European Regional Development Fund in the Operational Programme Research, Development and Education and The Czech Ministry of Education, Youth and Sports.

\section{References}

ABDELSALAM EEE, BANDOUCHOVA H, HEGER T, KANOVA M, KOBELKOVA K, NĚMCOVÁ M, PIAČEK V, SEDLACKOVA J, SEIDLOVA V, VITULA F, PIKULA J: Polychlorinated biphenyl toxicity in the thyroid gland of wild ungulates: an in vitro model. Acta Veterinaria Brno 89: 151-162, 2020. https://doi.org/10.2754/avb202089020151

AITHAL GP, DAY CP: Nonsteroidal anti-inflammatory drug-induced hepatotoxicity. Clin Liver Dis 11: 563-575, 2007. https://doi.org/10.1016/j.cld.2007.06.004

AJIMA MN, OGO OA, AUDU BS, UGWOEGBU KC: Chronic diclofenac (DCF) exposure alters both enzymatic and haematological profile of African catfish, Clarias gariepinus. Drug Chem Toxicol 38: 383-390, 2015. https://doi.org/10.3109/01480545.2014.974108

AL-SAEED A: Gastrointestinal and cardiovascular risk of nonsteroidal anti-inflammatory drugs. Oman Med J 26: 385 , 2011. https://doi.org/10.5001/omj.2011.101

ARNOLD KE, BOXALL ABA, BROWN AR, CUTHBURT RJ, GAW S, HUTCHINSON TH, JOBLING S, MADDEN JC, METCALFE CD, NAIDOO V, SHORE RF, SMITS JE, TAGGART MA, THOMPSON HM: Assessing the exposure risk and impacts of pharmaceuticals in the environment on individuals and ecosystems. Biol Lett 9: 1-4, 2013. https://doi.org/10.1098/rsbl.2013.0492

BEUTLER B: Innate immunity: an overview. Mol Immunol 40: 845-859, 2004. https://doi.org/10.1016/j.molimm.2003.10.005

BLY JE, CLEM LW: Temperature-mediated processes in teleost immunity: in vitro immunosuppression induced by in vivo low temperature in channel catfish. Vet Immunol Immunopathol 28: 365-377, 1991. https://doi.org/10.1016/0165-2427(91)90127-X

BOELSTERLI UA: Mechanisms of NSAID-induced hepatotoxicity. Drug safety 25: 633-648, 2002. https://doi.org/10.2165/00002018-200225090-00003

BORT R, PONSODA X, JOVER R, GÓMEZ-LECHÓN MJ, CASTELL JV: Diclofenac toxicity to hepatocytes: a role for drug metabolism in cell toxicity. J Pharmacol Exp Ther 288: 65-72, 1999.

BUSER HR, POIGER T, MÜLLER MD: Occurrence and fate of the pharmaceutical drug diclofenac in surface waters: rapid photodegradation in a lake. Environ Sci Technol 32: 3449-3456, 1998. https://doi.org/10.1021/es980301x

CAREY HV, ANDREWS MT, MARTIN SL: Mammalian hibernation: cellular and molecular responses to depressed metabolism and low temperature. Physiol Rev 83: 1153-1181, 2003. https://doi.org/10.1152/physrev.00008.2003 
CHANG JK, WANG GJ, TSAI ST, HO ML: Nonsteroidal anti-inflammatory drug effects on osteoblastic cell cycle, cytotoxicity, and cell death. Connective Tissue Res 46: 200-210, 2005. https://doi.org/10.1080/03008200500344025

CHANG JK, WU SC, WANG GJ, CHO MH, HO ML: Effects of non-steroidal anti-inflammatory drugs on cell proliferation and death in cultured epiphyseal-articular chondrocytes of fetal rats. Toxicology 228: 111-123, 2006. https://doi.org/10.1016/j.tox.2006.08.028

CHEN J, ZHOU XQ, FENG L, LIU Y, JIANG J: Effects of glutamine on hydrogen peroxide-induced oxidative damage in intestinal epithelial cells of Jian carp (Cyprinus carpio var. Jian). Aquaculture 288: 285-289, 2009. https://doi.org/10.1016/j.aquaculture.2008.10.053

CLEUVERS M: Mixture toxicity of the anti-inflammatory drugs diclofenac, ibuprofen, naproxen, and acetylsalicylic acid. Ecotoxicol Environ Saf 59: 309-315, 2004. https://doi.org/10.1016/S0147-6513(03)00141-6

DAUGHTON CG, RUHOY IS: Lower-dose prescribing: minimizing "side effects" of pharmaceuticals on society and the environment. Sci Total Environ 443: 324-337, 2013. https://doi.org/10.1016/j.scitotenv.2012.10.092

DERRINGER G, SUICH R: Simultaneous optimization of several response variables. J Qual Technol 12: 214-218, 1980. https://doi.org/10.1080/00224065.1980.11980968

DESAI A, GROLLEAU-JULIUS A, YUNG: Leukocyte function in the aging immune system. J Leucot Biol 87: 1001-1009, 2010. https://doi.org/10.1189/jlb.0809542

FILKINS JP: Comparison of endotoxin detoxification by leukocytes and macrophages. Proc Soc Exp Biol Med 137: 1396-1400, 1971. https://doi.org/10.3181/00379727-137-35797.

FORGET G, LEBEL J: An ecosystem approach to human health. Int J Occup Environ Health 7 (Suppl 2): S3-38, 2001.

HARDING RL, HALEVY O, YAHAV S, VELLEMAN SG: The effect of temperature on proliferation and differentiation of chicken skeletal muscle satellite cells isolated from different muscle types. Physiol Rep 4: e12770, 2016. https://doi.org/10.14814/phy2.12770

GROSSER T, FRIES S, FITZGERALD GA: Biological basis for the cardiovascular consequences of COX-2 inhibition: therapeutic challenges and opportunities. J Clin Investig 116: 4-15, 2006. https://doi.org/10.1172/JCI27291

HAWKEY CJ. Nonsteroidal anti-inflammatory drug gastropathy. Gastroenterology 119: 521-535, 2000. https://doi.org/10.1053/gast.2000.9561

HEGER T, ZUKAL J, SEIDLOVA V, NEMCOVA M, NECAS D, PAPEZIKOVA I, PIACEK V, ZAJICKOVA R, BANDOUCHOVA H, PIKULA J: Measurement of phagocyte activity in heterotherms. Acta Veterinaria Brno 89: 79-87, 2020. https://doi.org/10.2754/avb202089010079

HELFGOTT SM, SANDBERG-COOK J, ZAKIM D, NESTLER J: Diclofenac-associated hepatotoxicity. JAMA 264, 2660-2662, 1990. https://doi.org/10.1001/jama.264.20.2660

HICKEY EJ, RAJE RR, REID VE, GROSS SM, RAY SD: Diclofenac induced in vivo nephrotoxicity may involve oxidative stress-mediated massive genomic DNA fragmentation and apoptotic cell death. Free Radical Biol Med 31: 139-152, 2001. https://doi.org/10.1016/S0891-5849(01)00560-3

HOEGER B, KÖLLNER B, DIETRICH DR, HITZFELD B: Water-borne diclofenac affects kidney and gill integrity and selected immune parameters in brown trout (Salmo trutta f. fario). Aquatic Toxicol 75: 53-64, 2005. https://doi.org/10.1016/j.aquatox.2005.07.006

HRUBA H, ABDELSALAM EEE, ANISIMOV N, BANDOUCHOVA H, HAVELKOVA B, HEGER T, KANOVA M, KOVACOVA V, NEMCOVA M, PIACEK V, SEDLACKOVA J, VITULA F, PIKULA J: Reproductive toxicity of fluoroquinolones in birds. BMC Vet Res 15: 209, 2019. https://doi.org/10.1186/s12917-019-1957-y

ISLAS-FLORES H, GÓMEZ-OLIVÁN LM, GALAR-MARTÍNEZ M, COLÍN-CRUZ A, NERI-CRUZ N, GARCÍAMEDINA S: Diclofenac-induced oxidative stress in brain, liver, gill and blood of common carp (Cyprinus carpio). Ecotoxicol Environ Safety 92: 32-38, 2013. https://doi.org/10.1016/j.ecoenv.2013.01.025

KOŁODZIEJSKA J, KOŁODZIEJCZYK M: Diclofenac in the treatment of pain in patients with rheumatic diseases. Reumatologia 56: 174, 2018. https://doi.org/10.5114/reum.2018.76816

KOVACOVA V, ABDELSALAM EEE, BANDOUCHOVA H, BRICHTA J, HAVELKOVA B, PIACEK V, VITULA F, PIKULA J: Cytotoxicity of ketamine, xylazine and Hellabrunn mixture in liver-, heart- and kidney-derived cells from fallow deer. Neuroendocrinol Letters 37: 78-83, 2016.

KRAMMER PH, ARNOLD R, LAVRIK IN: Life and death in peripheral T cells. Nature Rev Immunol 7: 532-542, 2007. https://doi.org/10.1038/nri2115 
KRÜGER K, MOOREN FC: Exercise-induced leukocyte apoptosis. Exercise Immunol Rev 20, 2014.

LACINA P, MRAVCOVÁ L, VÁVROVÁ M: Application of comprehensive two-dimensional gas chromatography with mass spectrometric detection for the analysis of selected drug residues in wastewater and surface water. J Environ Sci 25: 204-212, 2013. https://doi.org/10.1016/S1001-0742(12)60006-0

LAINE L: Nonsteroidal anti-inflammatory drug gastropathy. Gastrointest Endosc Clin North America 6: 489-504, 1996. https://doi.org/10.1016/S1052-5157(18)30351-9

LIM M, LIM PL, GUPTA R., BOELSTERLI UA: Critical role of free cytosolic calcium, but not uncoupling, in mitochondrial permeability transition and cell death induced by diclofenac oxidative metabolites in immortalized human hepatocytes. Toxicol Appl Pharmacol 217: 322-331, 2006. https://doi.org/10.1016/j.taap.2006.09.012

LIU YJ, DU JL, CAO LP, JIA R, SHEN YJ, ZHAO CY, XU PP, YIN GJ: Anti-inflammatory and hepatoprotective effects of Ganoderma lucidum polysaccharides on carbon tetrachloride-induced hepatocyte damage in common carp (Cyprinus carpio L.). Int Immunopharmacol 25: 112-120, 2015. https://doi.org/10.1016/j.intimp.2015.01.023

LONAPPAN L, BRAR SK, DAS RK, VERMA M, SURAMPALLI RY: Diclofenac and its transformation products: environmental occurrence and toxicity - a review. Environ Int 96: 127-138, 2016. https://doi.org/10.1016/j.envint.2016.09.014

MARSIK P, REZEK J, ŽIDKOVÁ M, KRAMULOVÁ B, TAUCHEN J, VANĚK T: Non-steroidal anti-inflammatory drugs in the watercourses of Elbe basin in Czech Republic. Chemosphere 171: 97-105, 2017. https://doi.org/10.1016/j.chemosphere.2016.12.055

MARTINEZ LL, APARECIDA DE OLIVEIRA M, FORTES ZB: Influence of verapamil and diclofenac on leukocyte migration in rats. Hypertension 34: 997-1001, 1999. https://doi.org/10.1161/01.HYP.34.4.997

MAY JE, XU J, MORSE HR, AVENT ND, DONALDSON C: Toxicity testing: the search for an in vitro alternative to animal testing. Brit J Biomed Sci 66: 160-165, 2009. https://doi.org/10.1080/09674845.2009.11730265

MCGETTIGAN P, HENRY D: Use of non-steroidal anti-inflammatory drugs that elevate cardiovascular risk: an examination of sales and essential medicines lists in low-, middle-, and high-income countries. PLoS Med 10(2): e1001388, 2013. https://doi.org/10.1371/journal.pmed.1001388

MEZZELANI M, GORBI S, DA ROS, Z, FATTARINI D, D'ERRICO G, MILAN M, BARGELLONI L, REGOLI F: Ecotoxicological potential of non-steroidal anti-inflammatory drugs (NSAIDs) in marine organisms: Bioavailability, biomarkers and natural occurrence in Mytilus galloprovincialis. Marine Environ Res 121: 31-39, 2016. https://doi.org/10.1016/j.marenvres.2016.03.005

MORVAN C LE, TROUTAUD D, DESCHAUX P: Differential effects of temperature on specific and nonspecific immune defences in fish. J Exp Biol 201: 165-168, 1998.

MURRAY MD, BRATER DC: Renal toxicity of the nonsteroidal anti-inflammatory drugs. Ann Rev Pharmacol Toxicol 33: 435-465, 1993. https://doi.org/10.1146/annurev.pa.33.040193.002251

NĚMCOVÁ M: Bats cell culture: in vitro cytotoxicity model. Brno, 2018. University of Veterinary and Pharmaceutical Sciences Brno. Faculty of Veterinary Hygiene and Ecology. Master thesis.

NEUHEIMER AB, THRESHER RE, LYLE JM, SEMMENS JM: Tolerance limit for fish growth exceeded by warming waters. Nat Clim Change 1: 110-113, 2011. https://doi.org/10.1038/nclimate1084

NEUMANN NF, STAFFORD JL, BARREDA D, AINSWORTH AJ, BELOSEVIC M: Antimicrobial mechanisms of fish phagocytes and their role in host defense. Dev Comp Immunol 25: 807-825, 2001. https://doi.org/10.1016/S0145-305X(01)00037-4

NICOTERA P, LEIST M, MANZO L: Neuronal cell death: a demise with different shapes. Trends Pharmacol Sci 20: 46-51, 1999. https://doi.org/10.1016/S0165-6147(99)01304-8

NILES AL, MORAVEC RA, RISS TL: In vitro viability and cytotoxicity testing and same-well multi-parametric combinations for high throughput screening. Curr Chem Genomics 3: 33, 2009. https://doi.org/10.2174/1875397300903010033

ORBACH SM, LESS RR, KOTHARI A, RAJAGOPALAN P: In vitro intestinal and liver models for toxicity testing. ACS Biomater Sci Eng 3: 1898-1910, 2017. https://doi.org/10.1021/acsbiomaterials.6b00699 
OSICKOVA J, BANDOUCHOVA H, KOVACOVA V, KRAL J, NOVOTNY L, ONDRACEK K, POHANKA M, SEDLACKOVA J, SKOCHOVA H, VITULA F, PIKULA J: Oxidative stress and liver damage in birds exposed to diclofenac and lead. Acta Veterinaria Brno 83: 299-304, 2014. https://doi.org/10.2754/avb201483040299

OWA FD: Water pollution: sources, effects, control and management. Medit J Soc Sci 4: 65, 2013. https://doi.org/10.5901/mjss.2013.v4n8p65

PASKOVA V, PASKEROVA H, PIKULA J, BANDOUCHOVA H, SEDLACKOVA J, HILSCHEROVA K: Combined exposure of Japanese quails to cyanotoxins, Newcastle virus and lead: Oxidative stress responses. Ecotoxicol Environ Saf 74: 2082-2090, 2011. https://doi.org/10.1016/j.ecoenv.2011.07.014

PONSODA X, BORT R, JOVER R, GOMEZ-LECHON MJ, CASTELL JV: Molecular mechanism of diclofenac hepatotoxicity: Association of cell injury with oxidative metabolism and decrease in ATP levels. Toxicol in vitro 9: 439-444, 1995. https://doi.org/10.1016/0887-2333(95)00035-7

SCHWAIGER J, FERLING H, MALLOW U, WINTERMAYR H, NEGELE RD: Toxic effects of the non-steroidal anti-inflammatory drug diclofenac. Part I: histopathological alterations and bioaccumulation in rainbow trout. Aqua Toxicol 68: 141-150, 2004. https://doi.org/10.1016/j.aquatox.2004.03.014

SHEN S, MARCHICK MR, DAVIS MR, DOSS GA, POHL LR: Metabolic activation of diclofenac by human cytochrome P450 3A4: role of 5-hydroxydiclofenac. Chem Res Toxicol 12, 214-222, 1999. https://doi.org/10.1021/tx9802365

SMITH SM, WUNDER MB, NORRIS D A, SHELLMAN YG: A simple protocol for using a LDH-based cytotoxicity assay to assess the effects of death and growth inhibition at the same time. PloS one 6(11): e26908, 2011. https://doi.org/10.1371/journal.pone.0026908

STEPANOVA S, PRASKOVA E, CHROMCOVA L, PLHALOVA L, PROKES M, BLAHOVA J, SVOBODOVA Z: The effects of diclofenac on early life stages of common carp (Cyprinus carpio). Environ Toxicol Pharmacol 35: 454-460, 2013. https://doi.org/10.1016/j.etap.2012.09.011

STEPHENSON NG: Effects of temperature on reptilian and other cells. Development 16: 455-467, 1966. https://doi.org/10.1016/0042-207X(66)91752-0

SYED M, SKONBERG C, HANSEN SH: Mitochondrial toxicity of diclofenac and its metabolites via inhibition of oxidative phosphorylation (ATP synthesis) in rat liver mitochondria: Possible role in drug induced liver injury (DILI). Toxicol in vitro 31: 93-102, 2016. https://doi.org/10.1016/j.tiv.2015.11.020

TANG W, STEARNS RA, BANDIERA SM, ZHANG Y, RAAB C, BRAUN MP, DEAN DC, PANG J, LEUNG KH, DOSS GA, STRAUSS JR, KWEI GY, RUSHMORE TH, CHIU SL, BAILLIE TA. Studies on cytochrome P-450-mediated bioactivation of diclofenac in rats and in human hepatocytes: identification of glutathione conjugated metabolites. Drug Metab Dispos 27: 365-372, 1999.

TERNES TA: Occurrence of drugs in German sewage treatment plants and rivers. Water Res 32: 3245-3260, 1998. https://doi.org/10.1016/S0043-1354(98)00099-2

TIXIER C, SINGER HP, OELLERS S, MÜLLER SR: Occurrence and fate of carbamazepine, clofibric acid, diclofenac, ibuprofen, ketoprofen, and naproxen in surface waters. Environ Sci Technol 37: 1061-1068, 2003. https://doi.org/10.1021/es025834r

TURVEY SE, BROIDE DH: Innate immunity. J Allergy Clin Immunol 125 (Suppl 2): S24-S32, 2010. https://doi.org/10.1016/j.jaci.2009.07.016

VAN LEEUWEN JS, VREDENBURG G, DRAGOVIC S, TJONG TJ, VOS JC, VERMEULEN NP: Metabolism related toxicity of diclofenac in yeast as model system. Toxicol Lett 200: 162-168, 2011. https://doi.org/10.1016/j.toxlet.2010.11.010

WILHELM I, FAZAKAS C, KRIZBAI IA: In vitro models of the blood-brain barrier. Acta Neurobiol Exp 71: 113-128, 2011.

ZINSSTAG J, SCHELLING E, WALTNER-TOEWS D, TANNER M: From "one medicine" to "one health" and systemic approaches to health and well-being. Preventive Vet Med 101: 148-156, 2011. https://doi.org/10.1016/j.prevetmed.2010.07.003

ZUCCATO E, CALAMARI D, NATANGELO M, FANELLI R: Presence of therapeutic drugs in the environment. Lancet 355(9217): 1789-1790, 2000. https://doi.org/10.1016/S0140-6736(00)02270-4 